\title{
Polyphenols from Chilean Propolis and Pinocembrin Reduce MMP-9 Gene Expression and Activity in Activated Macrophages
}

\author{
Nicolás Saavedra, ${ }^{1}$ Alejandro Cuevas, ${ }^{1}$ Marcela F. Cavalcante, ${ }^{2}$ Felipe A. Dörr, ${ }^{2}$ \\ Kathleen Saavedra, ${ }^{1}$ Tomás Zambrano, ${ }^{1}$ Dulcineia S. P. Abdalla, ${ }^{2}$ and Luis A. Salazar ${ }^{1}$ \\ ${ }^{1}$ Center of Molecular Biology and Pharmacogenetics, Department of Basic Sciences, Scientific and Technological Bioresource Nucleus, \\ Universidad de La Frontera, Avenida Francisco Salazar 01145, 4811230 Temuco, Chile \\ ${ }^{2}$ Department of Clinical and Toxicological Analyses, Faculty of Pharmaceutical Sciences, Universidade de São Paulo, \\ Avenida Professor Lineu Prestes 580, 05508-000 São Paulo, SP, Brazil
}

Correspondence should be addressed to Luis A. Salazar; luis.salazar@ufrontera.cl

Received 16 December 2015; Accepted 7 March 2016

Academic Editor: Nikos Chorianopoulos

Copyright ( $) 2016$ Nicolás Saavedra et al. This is an open access article distributed under the Creative Commons Attribution License, which permits unrestricted use, distribution, and reproduction in any medium, provided the original work is properly cited.

\begin{abstract}
Polyphenols from diverse sources have shown anti-inflammatory activity. In the context of atherosclerosis, macrophages play important roles including matrix metalloproteinases synthesis involved in degradation of matrix extracellular components affecting the atherosclerotic plaque stability. We prepared a propolis extract and pinocembrin in ethanol solution. Propolis extract was chemically characterized using LC-MS. The effect of treatments on gene expression and proteolytic activity was measured in vitro using murine macrophages activated with LPS. Cellular toxicity associated with both treatments and the vehicle was determined using MTT and apoptosis/necrosis detection assays. MMP-9 gene expression and proteolytic activity were measured using qPCR and zymography, respectively. Thirty-two compounds were identified in the propolis extract, including pinocembrin among its major components. Treatment with either ethanolic extract of propolis or pinocembrin inhibits MMP-9 gene expression in a dosedependent manner. Similarly, an inhibitory effect was observed in proteolytic activity. However, the effect showed by ethanolic extract of propolis was higher than the effect of pinocembrin, suggesting that MMP-9 inhibition results from a joint contribution between the components of the extract. These data suggest a potential role of polyphenols from Chilean propolis in the control of extracellular matrix degradation in atherosclerotic plaques.
\end{abstract}

\section{Introduction}

Matrix metalloproteinases (MMPs) are a family of proteolytic enzymes involved in physiological processes associated with homeostasis regulation, host defense, and tissue repair. These proteins belong to a family of calcium-dependent, zinc-containing endopeptidases that degrade proteins and proteoglycan components of extracellular matrix (ECM) [1]. Diverse cellular types, including connective tissue cells, proinflammatory cells, osteoblasts, endothelial cells, neutrophils, lymphocytes, and macrophages, express MMPs. Regularly, the expression of these enzymes in physiological mechanisms is under strict control, playing an important role in ECM remodeling under normal conditions such as fetal tissue development and postnatal tissue repair [2].
In pathological events, deregulation of MMPs is frequent [3], and excessive breakdown of ECM is observed in connective tissue destruction and remodeling associated with cancer invasion and metastasis [4], cartilage destruction in arthritis [5], and atherosclerotic plaque rupture [6]. More specifically, the deregulation of MMP-9 expression has been associated with tumor invasiveness $[4,7,8]$, atherosclerotic plaque rupture in animals with advanced lesions [9], and acute coronary syndrome in humans [10]. MMP-9 or 92$\mathrm{kDa}$ gelatinase is expressed by activated macrophages and foam cells in atheroma plaque [11] and is specialized in the digestion of basement membrane collagens and elastin, facilitating macrophage extravasation $[12,13]$. MMP-9 expression is increased in inflammatory, malignant, and degenerative diseases, particularly in acute coronary syndrome in humans, 
where circulating MMP-9 levels are increased [10], suggesting that inhibition of MMP-9 activity might have a therapeutic potential.

Propolis is a polyphenol-rich resinous substance collected by honeybees from a variety of plant sources as trees and shrubs. Its colour is variable depending on the plant from which is collected, and its smell is intense and aromatic [14]. It is generally composed by fats, aliphatic and aromatic hydrocarbons, flavonoids, alcohols, terpenes, sugars, and esters. Its chemical composition is very complex and varies according to geographic origin depending on the local flora from which it was produced $[15,16]$, as well as bee species that performed the collection [17]. This variability results in differences between the biological properties showed by different extracts [18]. Propolis has been used as a complementary medicine since ancient times [19], demonstrating biological activity such as lipid lowering effects and antibacterial, antitumor, and anti-inflammatory effects [20-24]. In our country, there are reports of antifungal activity against Candida spp. [25] and hepatoprotective [26] and antioxidant activities [27]. Chemical characterization of Chilean propolis has identified pinocembrin among its main components, which also showed biological activity as an isolated compound [28-30]. Pinocembrin (5,7-dihydroxyflavanone) is one of the primary flavonoids in propolis, can be extracted as a pure compound, and has been incorporated in pharmaceutical industry for its wide range of pharmacological effects [30], including antimicrobial, anti-inflammatory, antioxidant, and anticancer activities [31-33].

Considering these antecedents, the aim of the present study was to evaluate the effect of polyphenols from Chilean propolis and pinocembrin on MMP-9 gene expression and gelatinolytic activity in activated macrophages.

\section{Materials and Methods}

2.1. Ethanolic Extract of Propolis (EEP) and Pinocembrin. An ethanolic extract was prepared from a propolis sample obtained from southern Chile (Cunco, La Araucanía). The sample was desiccated and frozen at $-20^{\circ} \mathrm{C}$. Then, the propolis $(150 \mathrm{~g})$ was pounded and macerated in $80 \%$ ethanol $(\mathrm{v} / \mathrm{v})$ protected from light for 30 minutes at $60^{\circ} \mathrm{C}$ under constant shaking. The resulting solution (EEP) was centrifuged $(5000 \times \mathrm{g}$ for 5 minutes) and filtered using first an AP20 prefilter (Millipore, USA) and then a $0.2 \mu \mathrm{m}$ hydrophobic filter (Millipore, USA), both in a vacuum filtration system. Later, the solvent was removed using a rotary evaporator. Finally, the resulting material was dissolved in a reduced volume of $80 \%$ ethanol $(\mathrm{v} / \mathrm{v})$ in order to obtain an EEP in which the solvent does not exceed $0.02 \% \mathrm{v} / \mathrm{v}$ of final concentration in the culture medium. Pinocembrin (Sigma-Aldrich Chemie $\mathrm{GmbH}$, Schnelldorf, Germany) was dissolved using the same solvent as EEP.

2.2. EEP Chemical Characterization. The EEP was characterized by liquid chromatography coupled to diode array detection and mass spectrometry (LC-DAD-MS). Chromatographic separation was achieved in a Shimadzu Prominence
(Kyoto, Japan) using a C-18 column $(250 \times 3.0 \mathrm{~mm}, 5 \mu \mathrm{m}$; Luna C-18(2), Phenomenex, CA, USA) at $40^{\circ} \mathrm{C}$. Gradient elution employed (A) water and (B) methanol both with $0.1 \%$ formic acid (30 to $60 \% \mathrm{~B}$ in $80 \mathrm{~min}, 0.5 \mathrm{~mL} / \mathrm{min}$ ). Mass spectrometry data was acquired with an Esquire HCT (Bruker Daltonics, MA, USA) after electrospray ionization in positive and negative modes. UV absorption profiles and fragmentation results (MS/MS) were compared to literature for compound assignments.

2.3. Cell Culture. RAW 264.7 cells were maintained in RPMI 1640 supplemented with $10 \%$ heat-inactivated fetal bovine serum (FBS), $2.0 \mathrm{~g} / \mathrm{L}$ sodium bicarbonate, $16.5 \mathrm{mmol} / \mathrm{L}$ HEPES, and $1 \mathrm{x}$ antibiotic/antimicotic mixture at $37^{\circ} \mathrm{C}$ in a $5 \%$ $\mathrm{CO}_{2}$ humidified atmosphere.

2.4. Cell Viability. To evaluate the effect of treatments on cell viability, we used the 3-(4,5-dimethylthiazol-2-yl)-2,5diphenyl tetrazolium bromide (MTT) reduction assay. RAW 264.5 cells $\left(5.0 \times 10^{3} /\right.$ well $)$ were seeded in a 96-well plate in the conditions above described, 12 hours before the experiment. The cells were treated with EEP or pinocembrin at concentrations within $1-10 \mu \mathrm{g} / \mathrm{mL}$ in presence or absence of LPS stimuli (100 ng/mL) during 12 hours. The effect of vehicle was also tested using it like treatments. Then, the medium was replaced by RPMI-without phenol red containing MTT ( $1 \mathrm{mg} / \mathrm{mL}$, Sigma Chemical Company, St. Louis, MO, USA) and the cells were incubated for 3 hours. After supernatant discarding, the precipitate was dissolved with dimethyl sulfoxide and the optical density was measured at $580 \mathrm{~nm}$ using a spectrophotometric microplate reader. Relative viability percentage with respect to the control cells was calculated.

2.5. Necrosis/Apoptosis Detection. As a complementary assay to evaluate cell viability, we performed necrosis/apoptosis detection in cells exposed to EEP, pinocembrin, or vehicle. RAW 264.5 cells $\left(3.0 \times 10^{5} /\right.$ well $)$ were seeded in a 24 -well plate in the conditions described above, 12 hours before the experiment. The cells were treated with EEP or pinocembrin at concentrations between 1 and $10 \mu \mathrm{g} / \mathrm{mL}$ under LPS stimuli $(100 \mathrm{ng} / \mathrm{mL})$ during 12 hours. The effect of the vehicle was also tested. As a positive control of cell death, we used cells exposed to $5 \%$ dimethyl sulfoxide. Treated cells were washed and then resuspended in reaction buffer. Annexin V-FITC and propidium iodide were added following the manufacturer's instructions (Sigma Chemical Company, St. Louis, MO, USA). The cells were incubated for 15 minutes at room temperature and were protected from light. Finally, cells were analyzed using a FACS Canto flow cytometer (BD Biosciences, San José, CA, USA). Data analysis was performed using FlowJo version 9.5.1 software (TreeStar). Cells without fluorescence emission were considered to calculate the relative viability percentage with respect to the control.

2.6. Gene Expression. RAW 264.7 cells $\left(4.0 \times 10^{5}\right.$ cells/well $)$ were plated and incubated in the conditions above described during 12 hours to allow cells adherence. Then, the fetal bovine serum content on culture media was reduced to $1 \%$ 
and the cells were stimulated with LPS $100 \mathrm{ng} / \mathrm{mL}$ (Sigma, USA) during 12 hours and were coincubated with noncytotoxic concentrations of EEP, pinocembrin, and the corresponding concentration of vehicle. At the end of treatment period, total RNA was obtained using Trizol ${ }^{\circledR}$ reagent following the manufacturer's indications (Invitrogen, Life Technologies, USA) and then quantified using a NanoDrop ${ }^{\mathrm{TM}} 1000$ spectrophotometer (Thermo Scientific, USA). $1 \mu \mathrm{g}$ of total RNA was reverse-transcribed using High Capacity RNA-tocDNA Master Mix (Applied Biosystems. Inc., USA). PCR assays were performed using a 7300 Real-Time PCR System (Applied Biosystems. Inc., USA) in a reaction containing $50 \mathrm{ng}$ of reverse-transcribed RNA, $200 \mathrm{nM}$ concentration of each primer, and $10 \mu \mathrm{L}$ of $2 \mathrm{x}$ Fast SYBR ${ }^{\circledR}$ Green Master Mix (Applied Biosystems. Inc., USA) on a final volume of $20 \mu \mathrm{L}$ under cycling conditions recommended by the manufacturer. Primers used were MMP-9F 5'-TG CCC ACC GTC CTT TCT TGT T-3', MMP-9R 5' -TGC TCG GAT GCA TCT GCA ACT-3', Rpl13aF 5' -TCC TCA AGA CCA ACG GAC TCC T-3', and Rpl13aR 5'-AAC CTT TGG TCC CCA CTT CCC T-3' for MMP-9 and Rpl13, respectively. The relative gene expression was analyzed using the qPCR database [28] in which the corresponding $\mathrm{Cq}$ was obtained using the Miner algorithm [29]. Rpl13a was used as reference gene.

2.7. Gelatinolytic Activity. RAW 264.7 cells $\left(4.0 \times 10^{5}\right.$ cells/ well) were plated and incubated in standard conditions during 12 hours. Then, the cells were washed and culture medium was replaced by serum-free media. The cells were activated with LPS $(100 \mathrm{ng} / \mathrm{mL})$ and coincubated with EEP, pinocembrin, or vehicle during 24 hours. The supernatant medium was collected and the protein concentration was measured using Modified Lowry Protein Assay Kit (Pierce Biotechnology Inc.). Then, $50 \mu \mathrm{g}$ of proteins was electrophoresed in a $10 \%$ acrylamide gel containing $1 \mathrm{mg} / \mathrm{mL}$ gelatin. After separation, gels were washed with $2.5 \%$ Triton $\mathrm{X}-100$ and incubated for 18 hours in a reaction buffer $(0.05 \mathrm{M}$ Tris- $\mathrm{HCl}$ (pH 8), $5 \mathrm{mmol} / \mathrm{L} \mathrm{CaCl}_{2}$, and $5 \mathrm{mmol} / \mathrm{L} \mathrm{ZnCl}_{2}$ ). Finally, gels were stained with Coomassie Brilliant Blue R250. Clear areas indicating gelatin lysis were quantified using the imageJ $1.46 \mathrm{r}$ software (National Institute of Health, USA).

2.8. Statistical Analysis. Results were analyzed using GraphPad Prism version 5.0a (GraphPad Software, San Diego CA, USA). Data are presented as mean \pm SD. Differences between groups involving continuous variables were evaluated by oneway ANOVA with Dunnett's posttest in those comparisons when significant differences were detected. Statistical significance was set at $\alpha=0.05$.

\section{Results}

3.1. Ethanolic Extract of Propolis Content and LC-DADMS Analysis. An ethanolic extract of propolis (EEP) was prepared from a propolis sample obtained from southern Chile (Cunco, La Araucanía). The chemical characterization of EEP by liquid chromatography coupled to diode array detection and mass spectrometry (LC-DAD-MS) detected

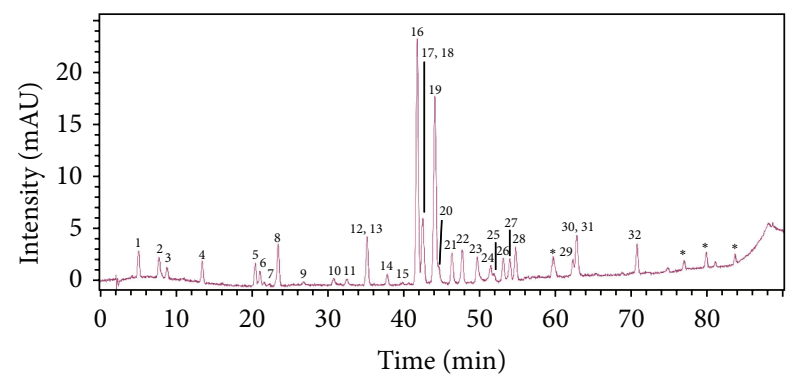

FIGURE 1: Chromatogram at $290 \mathrm{~nm}$ showing the main components found in the ethanolic extract of Chilean propolis. 1: caffeic acid; 2: p-coumaric acid; 3: ferulic/isoferulic acid; 4: 3,4-dimethylcaffeic acid; 5: pinobanksin-5-methyl ether; 6: p-coumaric methyl ester; 7: quercetin; 8: pinobanksin; 9: quercetin-3-methyl ether; 10: pinocembrin-5-methyl ether; 11: apigenin; 12: luteolin-5-methyl ether; 13: cinnamyliden acetic acid; 14: pinobanksin derivative; 15: isorhamnetin; 16: pinocembrin; 17: caffeic acid benzyl ester; 18: caffeic acid isoprenyl ester; 19: pinobanksin-3-O-acetate; 20: caffeic acid isoprenyl ester; 21: chrysin; 22: caffeic acid phenethyl ester (CAPE); 23: galangin; 24: chrysin methyl ether; 25: p-coumaric benzyl ester; 26: caffeic acid derivative; 27: pinobanksin-3-O-propionate; 28: caffeic acid cinnamyl ester; 29: pinobanksin-3-O-pentenoate; 30: p-coumaric cinnamyl ester; 31: pinobanksin-3-O-butyrate; 32: pinobanksin-3-O-pentanoate/2-methylbutyrate; *: unknown.

the presence of 36 compounds, successfully identifying 32 of them. The major components found in the extract were pinocembrin and derivatives of caffeic acid and pinobanksin (Figure 1).

3.2. EEP Treatment Does Not Affect Cell Viability in RAW 264.7 Cells. RAW 264.5 cells were treated with EEP or pinocembrin at concentrations within $1-10 \mu \mathrm{g} / \mathrm{mL}$ in presence or absence of lipopolysaccharide (LPS, $100 \mathrm{ng} / \mathrm{mL}$ ) stimuli. The effect of treatment on cell viability was evaluated by 3 (4,5-dimethylthiazol-2-yl)-2,5-diphenyl tetrazolium bromide (MTT) reduction assay. Figure 2 shows the relative viability of RAW 264.7 cells under experimental conditions described above. The activation of macrophages using LPS did not show variations with respect to control cells. Similarly, vehicle exposition did not alter the cell viability in either presence or absence of LPS stimuli. Regarding treatment exposition of activated RAW 264.7 cells, EEP and pinocembrin did not show significant variations at explored concentrations. Additionally, we assessed cell viability relative to control using a necrosis/apoptosis detection assay, in which no differences were observed up to $7.5 \mu \mathrm{g} / \mathrm{mL}$ of EEP. In pinocembrin and vehicle treated cells, no significant changes were observed (Figure 3).

3.3. Inhibition of MMP-9 Expression by EEP Treatment in RAW 264.7 Cells. The mRNA expression of MMP-9 in RAW 264.7 cells was evaluated by quantitative real-time PCR (qRTPCR). The vehicle did not affect MMP-9 gene expression in conditions of LPS-stimulation and unstimulated cells. Moreover, treatment with EEP showed a significant reduction in a dose dependent manner with higher inhibition at the highest 


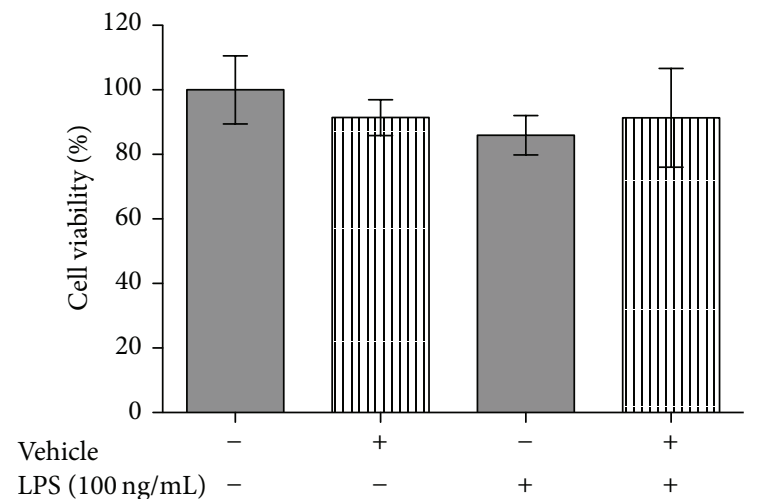

(a)

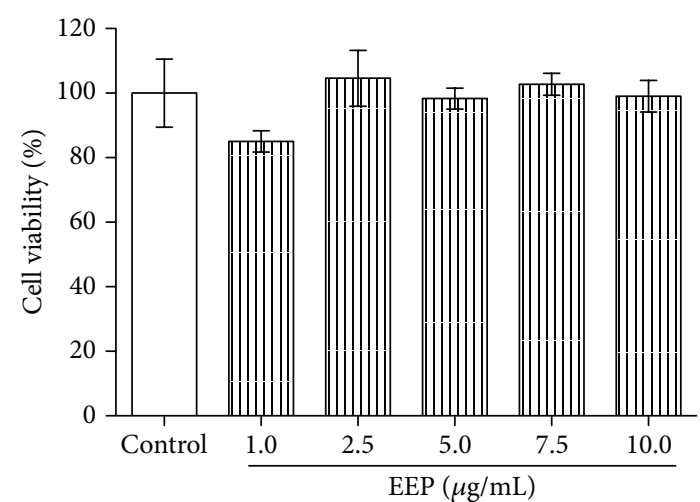

(b)

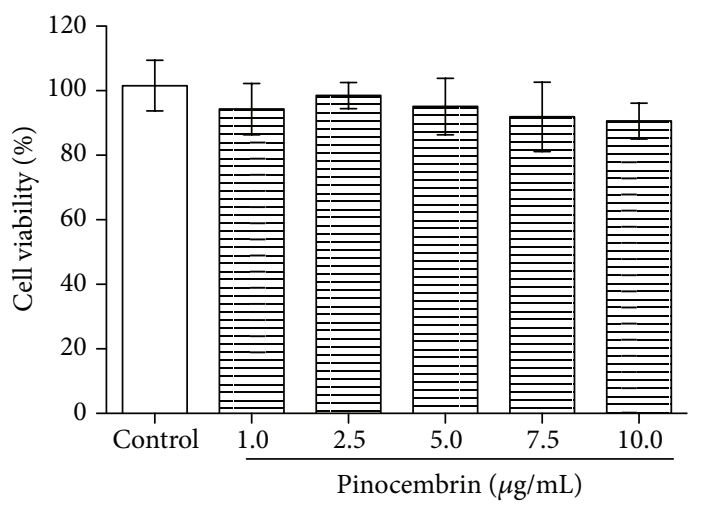

(c)

FIGURE 2: MTT cell viability assay for ethanolic extract of polyphenols, pinocembrin, or vehicle exposed cells. (a) Cell viability of vehicle exposed RAW 264.7 cells in presence or absence of LPS stimuli (100 ng/mL). (b) and (c) Effect of EEP and pinocembrin on cell viability of RAW 264.7 cells under LPS stimulus.

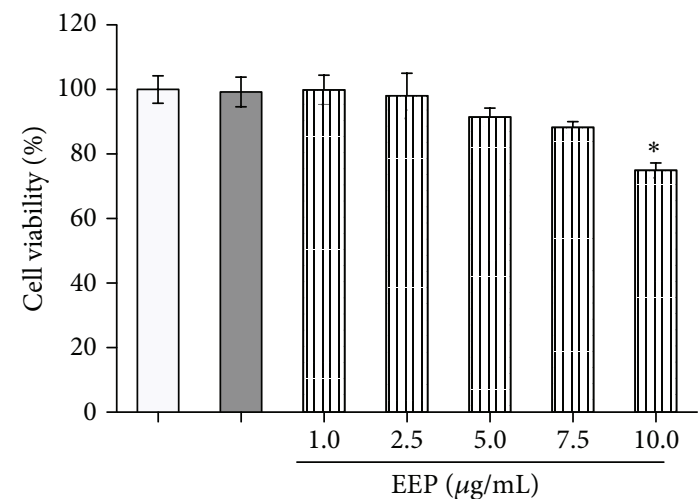

\begin{tabular}{ll}
$\square$ & Control \\
\hline & Vehicle
\end{tabular}

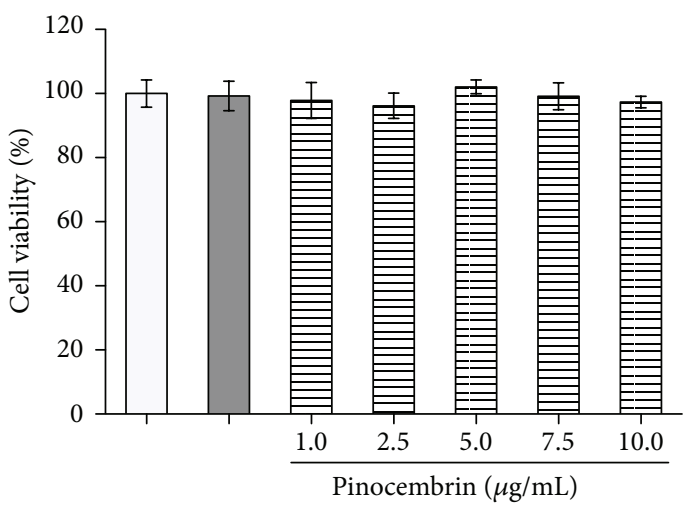

Control Vehicle

(a)

(b)

FIGURE 3: Necrosis/apoptosis detection in activated RAW 264.7 cells exposed to ethanolic extract of propolis, pinocembrin, and vehicle. (a) Effect of EEP $(1-10 \mu \mathrm{g} / \mathrm{mL})$ on cell viability by necrosis/apoptosis detection. (b) Effect of pinocembrin treatment $(1-10 \mu \mathrm{g} / \mathrm{mL})$ on cell viability by necrosis/apoptosis detection in RAW 264.7 cells under LPS stimulus. ${ }^{*}$ ANOVA: $p=0.004$; Dunnett's multiple comparison test: $p<0.05$. 


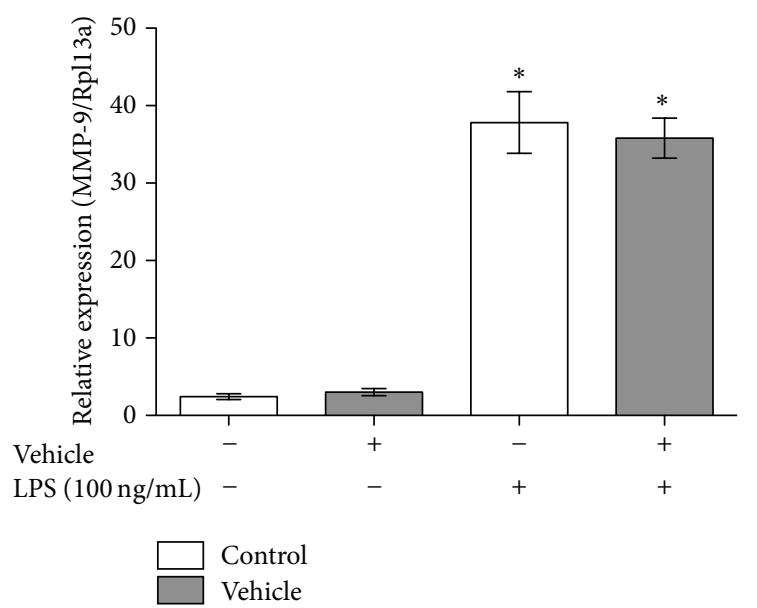

(a)

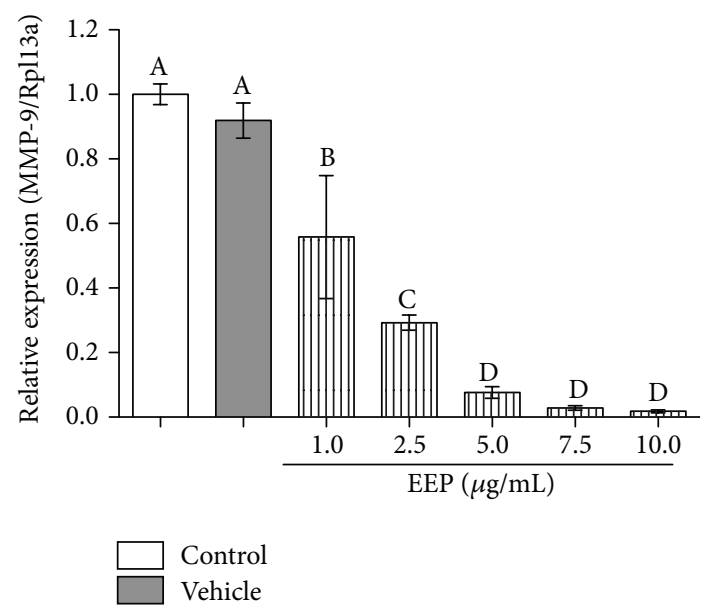

(b)

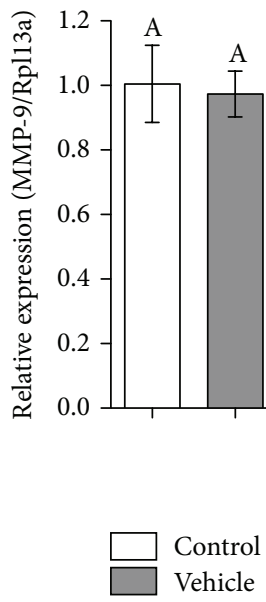

(c)

FIGURE 4: Effect of ethanolic extract of propolis, pinocembrin, and vehicle on relative gene expression of MMP-9. (a) Vehicle induced effect on MMP-9 gene expression in presence or absence of LPS stimulus. (b) Effect of EEP on MMP-9 relative gene expression. (c) Effect of pinocembrin on MMP-9 relative gene expression. Different letters indicate significant differences. *ANOVA: $p<0.0001$; Tukey's Multiple Comparison Test: $p<0.05$.

concentrations of treatment. Similarly, pinocembrin treated cells showed an inhibitory effect on MMP-9 mRNA expression. However, the effect exerted by pinocembrin treatment was lesser than the effect showed by the EEP treatment (Figure 4).

3.4. Inhibition of MMP-9 Activity by EEP Treatment. Finally, we evaluated the effect of EEP and pinocembrin on the gelatinolytic activity of MMP- 9 secreted by activated macrophages. In cells treated with EEP, we observed a significant reduction of collagen degradation starting at $2.5 \mu \mathrm{g} / \mathrm{mL}$, with an increasing effect at higher EEP concentrations. Pinocembrin treated cells also showed a significant reduction of collagen degradation, but to a lesser extent than EEP, affecting the gelatinolytic activity from $7.5 \mu \mathrm{g} / \mathrm{mL}$ of treatment (Figure 5).

\section{Discussion}

Biologic activity of polyphenols from several sources has been widely studied. Among the common sources, propolis offers complex mixtures to evaluate the joint effect of its constituents. The chemical composition of propolis samples is determined by factors as botanical and geographical origin [34]. These factors define a characteristic pattern of compounds, referred to as propolis fingerprinting [35]. South American propolis contains certain predominant compounds as Artepillin C and p-Coumaric acid found in Brazilian propolis $[36,37]$ and pinocembrin in Chilean propolis $[28,29]$. In the present study, we used a propolis sample collected from southern Chile. As aforementioned, pinocembrin was one of the predominant components. However, considering the large amount of caffeic acid and pinobanksin derivatives, probably these two compounds could also influence its biological activities and should be studied separately.

Evidence of biological activity of Chilean propolis has been shown in previous works by our group [38-41]. The present study demonstrates an inhibitory effect of EEP and pinocembrin on both gene expression and gelatinolytic 


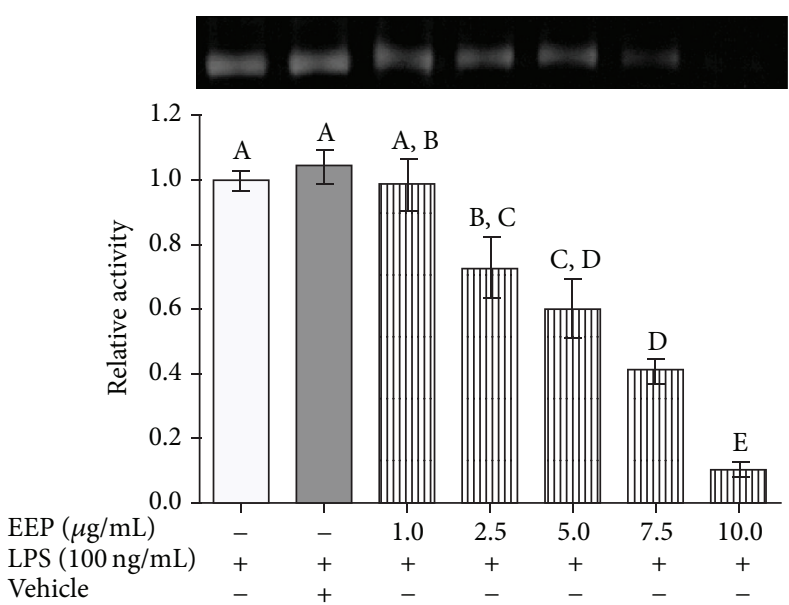

(a)

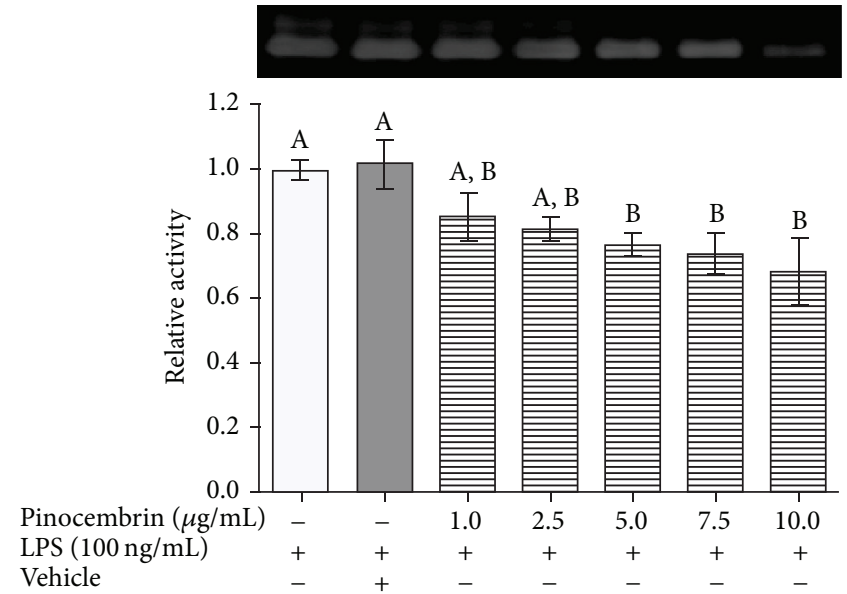

(b)

FIGURE 5: Effect of ethanolic extract of propolis, pinocembrin, and vehicle on gelatinolytic activity of MMP-9. (a) Effect of EEP on MMP9 relative proteolytic activity. (b) MMP-9 relative proteolytic activity of pinocembrin treated cells. Different letters indicate significant differences.

activity of MMP-9 using a cellular model of activated macrophages (LPS $100 \mathrm{ng} / \mathrm{mL}$ ). LPS stimuli result in the induction of numerous inflammatory mediators as cytokines and chemokines including TNF- $\alpha$, IL-1, IL-6, and MCP-1. This effect is associated with the activity of inflammationrelated transcription factors as NF-kappa B [42], also involved in MMP-9 expression [43]. In atherosclerosis development, matrix metalloproteinases are mainly secreted by macrophages. These enzymes are involved in vascular remodeling allowing the adaptation of affected vessel to the vascular injury in order to maintain the lumen diameter, mechanism modulated by wall components and extracellular matrix, especially by its degradation. However, MMP-9 proteolytic activity has been associated with the progression of atherosclerotic plaques to a vulnerable state and consequently to the development of ischemic events $[10,44-47]$. Matrix metalloproteinases are also involved in other diseaseassociated processes such as cell invasion and metastasis in cancer [48]. In this context, using an in vitro model of hepatocellular carcinoma, treatment with polyphenols from propolis in concentrations similar to those used in the present work did inhibit the activity of MMP-9, similar to the effect associated with caffeic acid phenethyl ester treatment obtained from the propolis sample [49]. This effect on MMP-9 has also been demonstrated by other isolated compounds as kaempferol, apigenin, resveratrol, and quercetin [50, 51]. Pinocembrin exhibits antibacterial, antiinflammatory, anticancer, and neuroprotective activities [30], and the anti-inflammatory effect exerted by pinocembrin has been associated with suppression of $\mathrm{I} \kappa \mathrm{B} \alpha$, JNK, and p38MAPK activation [30,52], signaling pathways involved in MMP-9 induction in LPS-stimulated macrophages $[53,54]$. Our study compared the effect of pinocembrin and EEP, obtaining an inhibitory effect on both gene expression and proteolytic activity. However, the modulation demonstrated using this particular flavonoid as treatment was lesser than that exhibited by EEP, which has, among its components, detectable amounts of all compounds listed above except for resveratrol. So, the observed effect can be a product of the joint activity of identified compounds. In conclusion, polyphenolic components of Chilean propolis show a significant inhibition of MMP-9 gene expression and activity, suggesting a potential role in the control of extracellular matrix degradation in atherosclerotic plaques and subsequently on plaque stability.

\section{Conclusion}

In summary, our results indicate that components of Chilean propolis showed a significant inhibition of MMP-9 gene expression and activity, suggesting a potential role in the control of extracellular matrix degradation in atherosclerotic plaques and subsequently on plaque stability.

\section{Competing Interests}

The authors declare that there is no conflict of interests regarding the publication of this paper.

\section{Acknowledgments}

Nicolás Saavedra, Alejandro Cuevas, Kathleen Saavedra, and Tomás Zambrano were the recipients of fellowships from CONICYT, Chile. This study was supported by grants from CONICYT (Chile), FAPESP-Brazil, UFRO-FAPESP 2014/50238-6, and CAPES-Brazil. Nicolás Saavedra is the recipient of Postdoctoral Fellowship from Convenio de Desempeño, Universidad de La Frontera. 


\section{References}

[1] I. Massova, L. P. Kotra, R. Fridman, and S. Mobashery, "Matrix metalloproteinases: structures, evolution, and diversification," The FASEB Journal, vol. 12, no. 12, pp. 1075-1095, 1998.

[2] J. F. Strauss III, "Extracellular matrix dynamics and fetal membrane rupture," Reproductive Sciences, vol. 20, no. 2, pp. 140-153, 2013.

[3] L. Nissinen and V.-M. Kähäri, "Matrix metalloproteinases in inflammation," Biochimica et Biophysica Acta, vol. 1840, no. 8, pp. 2571-2580, 2014.

[4] A. Merdad, S. Karim, H.-J. Schulten et al., "Expression of matrix metalloproteinases (MMPs) in primary human breast cancer: MMP-9 as a potential biomarker for cancer invasion and metastasis," Anticancer Research, vol. 34, no. 3, pp. 1355-1366, 2014.

[5] L. Lipari and A. Gerbino, "Expression of gelatinases (MMP-2, MMP-9) in human articular cartilage," International Journal of Immunopathology and Pharmacology, vol. 26, no. 3, pp. 817-823, 2013.

[6] A. C. Newby, "Metalloproteinases promote plaque rupture and myocardial infarction: a persuasive concept waiting for clinical translation," Matrix Biology, vol. 44-46, pp. 157-166, 2015.

[7] J. Chen, X. Liu, H. Jiao et al., "Prognostic and clinical significance of STAT3 and MMP9 in patients with gastric cancer: a meta-analysis of a Chinese cohort," International Journal of Clinical and Experimental Medicine, vol. 8, no. 1, pp. 546-557, 2015.

[8] G. Shay, C. C. Lynch, and B. Fingleton, "Moving targets: emerging roles for MMPs in cancer progression and metastasis," Matrix Biology, vol. 44-46, pp. 200-206, 2015.

[9] P. J. Gough, I. G. Gomez, P. T. Wille, and E. W. Raines, "Macrophage expression of active MMP-9 induces acute plaque disruption in apoE-deficient mice," The Journal of Clinical Investigation, vol. 116, no. 1, pp. 59-69, 2006.

[10] I. M. Loftus, A. R. Naylor, S. Goodall et al., "Increased matrix metalloproteinase-9 activity in unstable carotid plaques. A potential role in acute plaque disruption," Stroke, vol. 31, no. 1, pp. 40-47, 2000.

[11] Z. S. Galis, G. K. Sukhova, R. Kranzhöfer, S. Clark, and P. Libby, "Macrophage foam cells from experimental atheroma constitutively produce matrix-degrading proteinases," Proceedings of the National Academy of Sciences of the United States of America, vol. 92, no. 2, pp. 402-406, 1995.

[12] G. Cimmino, M. Ragni, P. Cirillo et al., "C-reactive protein induces expression of matrix metalloproteinase-9: a possible link between inflammation and plaque rupture," International Journal of Cardiology, vol. 168, no. 2, pp. 981-986, 2013.

[13] F. Chen, P. Eriksson, G. K. Hansson et al., "Expression of matrix metalloproteinase 9 and its regulators in the unstable coronary atherosclerotic plaque," International Journal of Molecular Medicine, vol. 15, no. 1, pp. 57-65, 2005.

[14] P. G. Pietta, C. Gardana, and A. M. Pietta, "Analytical methods for quality control of propolis," Fitoterapia, vol. 73, supplement 1, pp. S7-S20, 2002.

[15] A. Daugsch, C. S. Moraes, P. Fort, and Y. K. Park, "Brazilian red propolis-chemical composition and botanical origin," Evidence-Based Complementary and Alternative Medicine, vol. 5, no. 4, pp. 435-441, 2008.

[16] M. I. Nieva Moreno, M. I. Isla, N. G. Cudmani, M. A. Vattuone, and A. R. Sampietro, "Screening of antibacterial activity of
Amaicha del Valle (Tucuman, Argentina) propolis," Journal of Ethnopharmacology, vol. 68, no. 1-3, pp. 97-102, 1999.

[17] S. Silici and S. Kutluca, "Chemical composition and antibacterial activity of propolis collected by three different races of honeybees in the same region," Journal of Ethnopharmacology, vol. 99, no. 1, pp. 69-73, 2005.

[18] V. S. Bankova, S. L. de Castro, and M. C. Marcucci, "Propolis: recent advances in chemistry and plant origin," Apidologie, vol. 31, no. 1, pp. 3-15, 2000.

[19] S. Castaldo and F. Capasso, "Propolis, an old remedy used in modern medicine," Fitoterapia, vol. 73, supplement 1, pp. S1-S6, 2002.

[20] Y.-B. Ghasem, A. Ownagh, and M. Hasanloei, "Antibacterial and antifungal activity of Iranian propolis against Staphylococcus aureus and Candida albicans," Pakistan Journal of Biological Sciences, vol. 10, no. 8, pp. 1343-1345, 2007.

[21] A. Uzel, K. Sorkun, Ö. Önçağ, D. Çoğulu, Ö. Gençay, and B. Salih, "Chemical compositions and antimicrobial activities of four different Anatolian propolis samples," Microbiological Research, vol. 160, no. 2, pp. 189-195, 2005.

[22] I. Ichi, H. Hori, Y. Takashima et al., "The beneficial effect of propolis on fat accumulation and lipid metabolism in rats fed a high-fat diet," Journal of Food Science, vol. 74, no. 5, pp. H127H131, 2009.

[23] H. Pratsinis, D. Kletsas, E. Melliou, and I. Chinou, "Antiproliferative activity of Greek propolis," Journal of Medicinal Food, vol. 13, no. 2, pp. 286-290, 2010.

[24] M. Viuda-Martos, Y. Ruiz-Navajas, J. Fernández-López, and J. A. Pérez-Álvarez, "Functional properties of honey, propolis, and royal jelly," Journal of Food Science, vol. 73, no. 9, pp. R117R124, 2008.

[25] C. L. Herrera, M. Alvear, L. Barrientos, G. Montenegro, and L. A. Salazar, "The antifungal effect of six commercial extracts of Chilean propolis on Candida spp," Ciencia e Investigación Agraria, vol. 37, no. 1, pp. 75-84, 2010.

[26] C. L. Herrera, O. Fritz, G. Montenegro, M. Alvear, M. del Sol, and L. A. Salazar, "El Propóleos Reduce la Esteatosis Hepática Inducida por Dieta en Ratones," International Journal of Morphology, vol. 28, no. 1, pp. 75-84, 2010.

[27] A. Russo, V. Cardile, F. Sanchez, N. Troncoso, A. Vanella, and J. A. Garbarino, "Chilean propolis: antioxidant activity and antiproliferative action in human tumor cell lines," Life Sciences, vol. 76, no. 5, pp. 545-558, 2004.

[28] S. Kumazawa, T. Hamasaka, and T. Nakayama, "Antioxidant activity of propolis of various geographic origins," Food Chemistry, vol. 84, no. 3, pp. 329-339, 2004.

[29] C. L. Herrera, M. Alvear, L. Barrientos, G. Montenegro, and L. A. Salazar, "The antifungal effect of six commercial extracts of Chilean propolis on Candida spp.," Ciencia e Investigacion Agraria, vol. 37, no. 1, pp. 75-84, 2010.

[30] A. Rasul, F. M. Millimouno, W. Ali Eltayb, M. Ali, J. Li, and X. Li, "Pinocembrin: a novel natural compound with versatile pharmacological and biological activities," BioMed Research International, vol. 2013, Article ID 379850, 9 pages, 2013.

[31] M. A. Saad, R. M. Abdel Salam, S. A. Kenawy, and A. S. Attia, "Pinocembrin attenuates hippocampal inflammation, oxidative perturbations and apoptosis in a rat model of global cerebral ischemia reperfusion," Pharmacological Reports, vol. 67, no. 1, pp. 115-122, 2015.

[32] C.-L. Hsu, Y.-S. Yu, and G.-C. Yen, "Anticancer effects of Alpinia pricei Hayata roots," Journal of Agricultural and Food Chemistry, vol. 58, no. 4, pp. 2201-2208, 2010. 
[33] X. Lan, W. Wang, Q. Li, and J. Wang, "The natural flavonoid pinocembrin: molecular targets and potential therapeutic applications," Molecular Neurobiology, vol. 53, no. 3, pp. 1794-1801, 2016.

[34] V. Bankova, "Recent trends and important developments in propolis research," Evidence-Based Complementary and Alternative Medicine, vol. 2, no. 1, pp. 29-32, 2005.

[35] J. Zhou, Y. Li, J. Zhao, X. Xue, L. Wu, and F. Chen, "Geographical traceability of propolis by high-performance liquidchromatography fingerprints," Food Chemistry, vol. 108, no. 2, pp. 749-759, 2008.

[36] Y. K. Park, J. F. Paredes-Guzman, C. L. Aguiar, S. M. Alencar, and F. Y. Fujiwara, "Chemical constituents in Baccharis dracunculifolia as the main botanical origin of southeastern brazilian propolis," Journal of Agricultural and Food Chemistry, vol. 52, no. 5, pp. 1100-1103, 2004.

[37] M. C. Marcucci, F. Ferreres, C. García-Viguera et al., "Phenolic compounds from Brazilian propolis with pharmacological activities," Journal of Ethnopharmacology, vol. 74, no. 2, pp. 105$112,2001$.

[38] L. Barrientos, C. L. Herrera, G. Montenegro et al., "Chemical and botanical characterization of chilean propolis and biological activity on cariogenic bacteria Streptococcus mutans and Streptococcus sobrinus," Brazilian Journal of Microbiology, vol. 44, no. 2, pp. 577-585, 2013.

[39] N. Saavedra, L. Barrientos, C. L. Herrera, M. Alvear, G. Montenegro, and L. A. Salazar, "Effect of Chilean propolis on cariogenic bacteria Lactobacillus fermentum," Ciencia e Investigación Agraria, vol. 38, no. 1, pp. 117-125, 2011.

[40] A. Pacheco, J. B. Daleprane, V. S. Freitas et al., "Effect of chilean propolis on glucose metabolism in diabetic mice," International Journal of Morphology, vol. 29, no. 3, pp. 754-761, 2011.

[41] J. B. Daleprane, V. da Silva Freitas, A. Pacheco et al., "Antiatherogenic and anti-angiogenic activities of polyphenols from propolis," The Journal of Nutritional Biochemistry, vol. 23, no. 6, pp. 557-566, 2012.

[42] M. Guha and N. Mackman, "LPS induction of gene expression in human monocytes," Cellular Signalling, vol. 13, no. 2, pp. 8594, 2001.

[43] W. R. Jae, K.-W. Lee, D. Kim et al., "NF- $\kappa$ B-dependent regulation of matrix metalloproteinase- 9 gene expression by lipopolysaccharide in a macrophage cell line RAW 264.7," Journal of Biochemistry and Molecular Biology, vol. 40, no. 1, pp. 88-94, 2007.

[44] I. M. Loftus, A. R. Naylor, P. R. F. Bell, and M. M. Thompson, "Matrix metalloproteinases and atherosclerotic plaque instability," British Journal of Surgery, vol. 89, no. 6, pp. 680-694, 2002.

[45] J. D. Raffetto and R. A. Khalil, "Matrix metalloproteinases and their inhibitors in vascular remodeling and vascular disease," Biochemical Pharmacology, vol. 75, no. 2, pp. 346-359, 2008.

[46] G. Pasterkamp, A. H. Schoneveld, D. J. Hijnen et al., "Atherosclerotic arterial remodeling and the localization of macrophages and matrix metalloproteases 1, 2 and 9 in the human coronary artery," Atherosclerosis, vol. 150, no. 2, pp. 245-253, 2000.

[47] S. Blankenberg, H. J. Rupprecht, O. Poirier et al., "Plasma concentrations and genetic variation of matrix metalloproteinase 9 and prognosis of patients with cardiovascular disease," Circulation, vol. 107, no. 12, pp. 1579-1585, 2003.

[48] E. I. Deryugina and J. P. Quigley, "Matrix metalloproteinases and tumor metastasis," Cancer and Metastasis Reviews, vol. 25, no. 1, pp. 9-34, 2006.
[49] U.-H. Jin, T.-W. Chung, S.-K. Kang et al., "Caffeic acid phenyl ester in propolis is a strong inhibitor of matrix metalloproteinase- 9 and invasion inhibitor: isolation and identification," Clinica Chimica Acta, vol. 362, no. 1-2, pp. 57-64, 2005.

[50] J. Majtan, J. Bohova, R. Garcia-Villalba et al., "Fir honeydew honey flavonoids inhibit TNF- $\alpha$-induced MMP-9 expression in human keratinocytes: a new action of honey in wound healing," Archives of Dermatological Research, vol. 305, no. 7, pp. 619-627, 2013.

[51] E. Scoditti, N. Calabriso, M. Massaro et al., "Mediterranean diet polyphenols reduce inflammatory angiogenesis through MMP9 and COX-2 inhibition in human vascular endothelial cells: a potentially protective mechanism in atherosclerotic vascular disease and cancer," Archives of Biochemistry and Biophysics, vol. 527, no. 2, pp. 81-89, 2012.

[52] L. W. Soromou, X. Chu, L. Jiang et al., "In vitro and in vivo protection provided by pinocembrin against lipopolysaccharideinduced inflammatory responses," International Immunopharmacology, vol. 14, no. 1, pp. 66-74, 2012.

[53] C.-H. Woo, J.-H. Lim, and J.-H. Kim, "Lipopolysaccharide induces matrix metalloproteinase- 9 expression via a mitochondrial reactive oxygen species-p38 kinase-activator protein-1 pathway in raw 264.7 cells," Journal of Immunology, vol. 173, no. 11, pp. 6973-6980, 2004.

[54] Y.-S. Lee, H. T. L. Tran, and V. T. Quang, "Regulation of expression of matrix metalloproteinase- 9 by JNK in Raw 264.7 cells: presence of inhibitory factor(s) suppressing MMP-9 induction in serum and conditioned media," Experimental and Molecular Medicine, vol. 41, no. 4, pp. 259-268, 2009. 

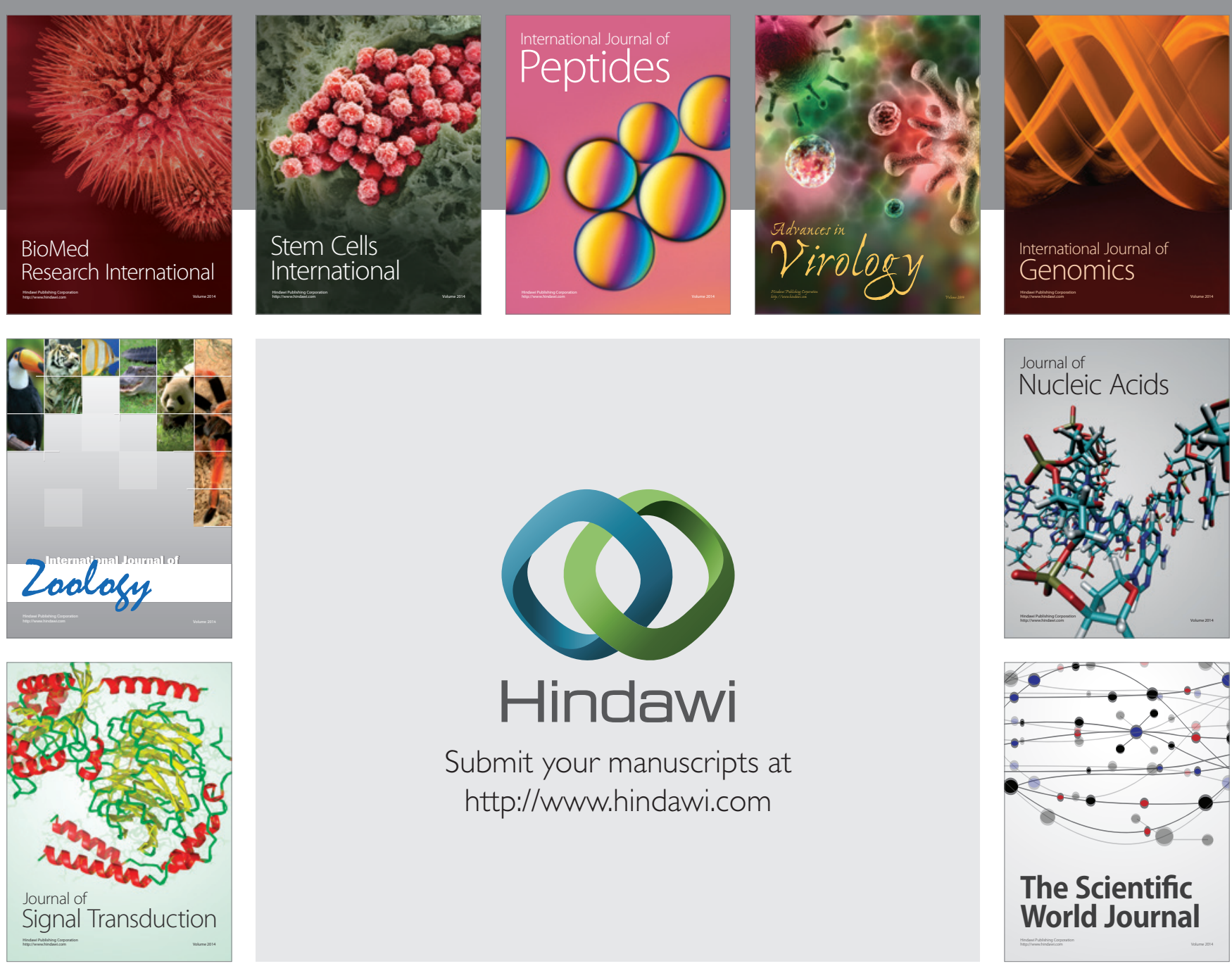

Submit your manuscripts at

http://www.hindawi.com
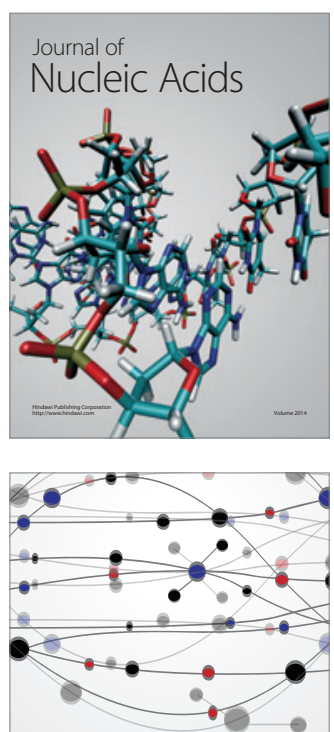

The Scientific World Journal
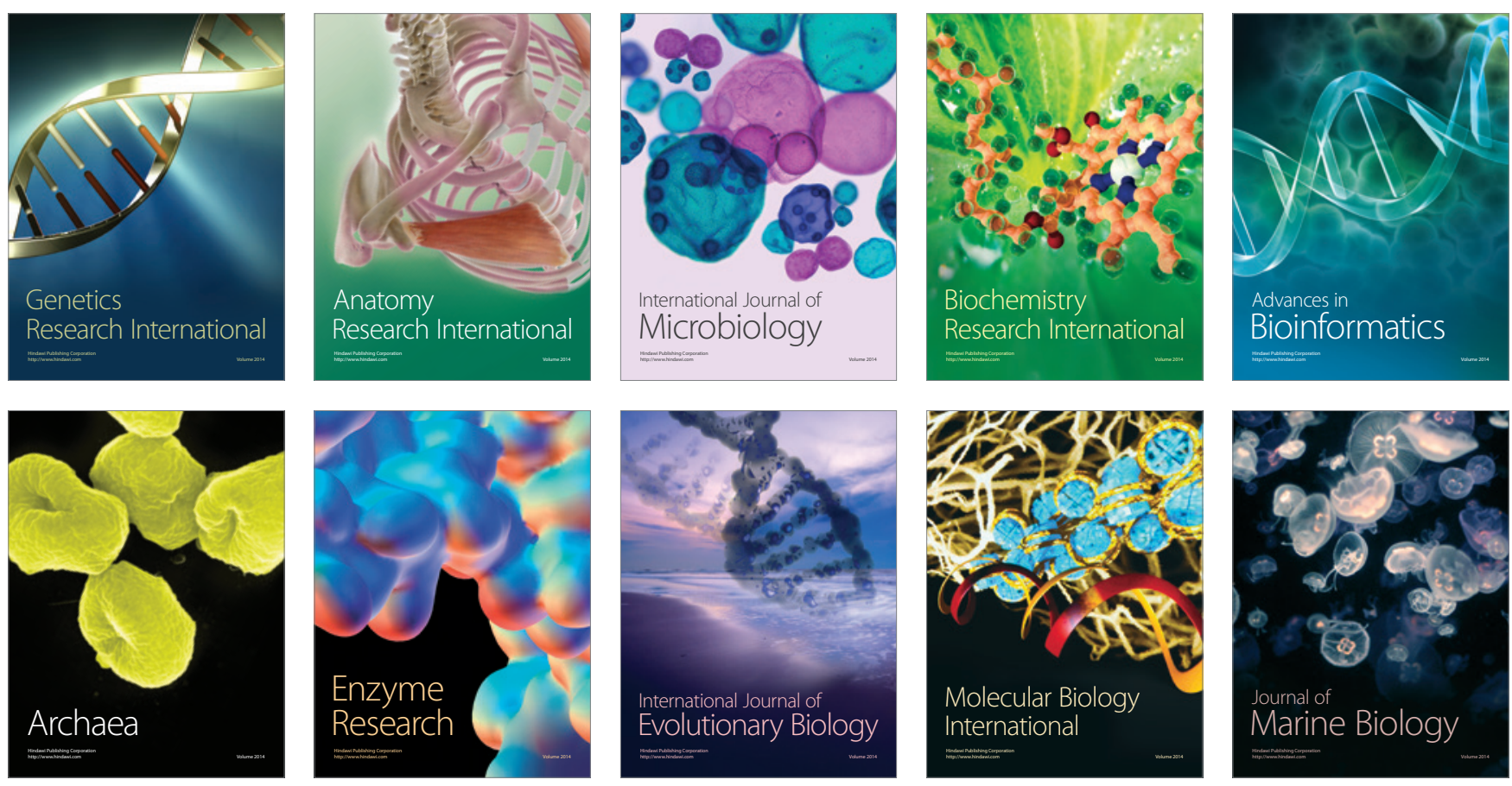